\title{
Perancangan E-CRM Dalam Mengatasi Keluhan Pelanggan Pada Samudera Jaya Printing
}

\author{
E-CRM Design In Dealing With Customer Complaints On Samudra Jaya Printing \\ Rezeki Ramadhani ${ }^{1}$, Fujiati, ${ }^{2}$, Dahri Yani Hakim Tanjung ${ }^{3}$ \\ ${ }^{1,2,3}$ Program Studi Sistem Informasi,Fakultas Teknik, Universitas Potensi Utama \\ Jl.K.L. Yos Sudarso KM 6.5 Tanjung Mulia-Medan \\ E-mail: rezekiramadhani02@gmail.com ${ }^{1}$, fuji.potensiutama@gmail.com², \\ dahriyanihakim@gmail.com ${ }^{3}$
}

\begin{abstract}
ABSTRAK
Samudera Jaya Printing merupakan perusahaan yang bergerak di bidang produksi produk percetakan dan penjualan produk percetakan yang bertipe make to order dimana sistem perencanaan produksi dilakukan setelah ada permintaan. Sistem yang berjalan pada perusahaan masih menggunakan aplikasi sederhana, sehingga pelanggan sangat sulit mengetahui informasi produk dan melakukan pemesanan produk harus datang langsung atau menghubungi pihak perusahaan untuk melakukan proses pemesanan produk, kemudian pihak perusahaan akan konfirmasi pemesanan produk, setelah itu melakukan proses pembayaran pemesanan produk dengan datang langsung pada perusahaan. Salah satu konsep yang dapat diadopsi untuk merespon hal ini adalah dengan menerapkan suatu Customer Relationship Management yang dapat menghubungkan perusahaan dan customer secara langsung (online) yang disebut E-CRM. Ada banyak sekali alasan mengapa penerapan E-CRM sangat penting untuk perusahaan. Melalui pengunaan E-CRM perusahaan bisa mendapatkan manfaat untuk penjualan, pemasaran, pelayanan dan juga aktivitas perusahaan lainnya. E-CRM juga dapat mempermudah pelanggan dalam mendapatkan informasi yang diperlukan dari perusahaan tersebut. Hal ini menjadi sarana untuk mempertahankan hubungan perusahaan dengan pelanggan demi mewujudkan loyalitas pelanggan, dengan merancang system yang baru maka pelanggan dan pihak perusahaan akan dapat melakukan kerja sama yang baik dengan transaksi pemasaran.
\end{abstract}

Kata Kunci : Customer Relationship Management, Pelayanan, Kuisoner, PHP, Mysql

\section{ABSTRACT}

Samudera Jaya Printing is a company engaged in the production of printing products and the sale of print products of the make to order type where the production planning system is carried out after a request. The system that runs at the company still uses a simple application, so that customers find it very difficult to find out product information and place an order for the product must come directly or contact the company to carry out the product order process, then the company will confirm the product order, after that make the product order payment process with come directly to the company. One of the concepts that can be adopted to respond to this is by implementing a Customer Relationship Management that can connect companies and customers directly (online) called E-CRM. There are many reasons why implementing E-CRM is so important for companies. Through the use of E-CRM, companies can get benefits for sales, marketing, service and other company activities. E-CRM can also make it easier for customers to get the necessary information from the company. This is a means to maintain company relationships with customers in order to achieve customer loyalty, by designing a new system, customers and the company will be able to work together well with marketing transactions.

Keywords: Customer Relationship Management, Services, Questionnaire, PHP, Mysql 


\section{PENDAHULUAN}

Customer Relationship Management (CRM) merupakan salah satu sarana untuk menjalin hubungan yang berkelanjutan antara perusahaan dengan pelanggan, dengan memanfaatkan CRM perusahaan akan mengetahui apa yang diharapkan dan diperlukan pelanggannya, strategi pengelolaan pelanggan, mulai dari proses pemasaran, penjualan sampai dengan pelayanan setelah penjualan, yang bertujuan untuk meningkatkan kepuasan pelanggan, yang berujung pada loyalitas pelanggan tersebut Bentuk E-CRM berupa media online yang paling umum digunakan adalah website portal perusahaan dikarenakan kemudahan dalam membuat website, biaya yang tidak terlalu mahal, dan dapat diakses oleh siapa saja. (Ariga, 2018).

Menurut Mas Ayoe Elhias Nst (2017) Metode CRM merupakan salah satau metode yang harus diterapkan oleh perusahaan untuk menarik pelanggan baru dan mempertahan pelanggan yang ada dan mempermudah proses transaksi penjualan.

Menurut Susanto (2020) Kinerja Customer Services adalah salah satu penyebab pengaruhnya kualitas pelayanan terhadap kepuasan pelanggan.

Menurut Eka Wahyuni (2019) Untuk meningkatkan loyalitas konsumen, perusahaan harus menerapkan strategi pemasaran dan pelayanan yang optimal dengan menganalisa faktor-faktor yang mempengaruhi tingkat kepuasan pelanggan.

Menurut Mas Ayoe Elhias Nst (2018) Dengan adanya Customer Service yang handal, konsumen dapat menikmati pelayanan yang diberikan perusahaan. Standart pelayanan dapat diartikan dengan tercapainya suatu penilaian dari kualitas pelayanan dari customer service.

Menurut Fujiati (2015) Dengan memafaatkan teknologi yang ada maka pelayanan jasa menjadi lebih efisien dengan menerapkan yaitu sistem Containeriasasi, dimana sstem berfungsi untuk mengoptimalkan dan mempermudah pelayanan jasa import peti kemas.

\section{METODE PENELITIAN}

2.1 Metode Pengembangan Sistem

Pengembangan sistem dapat berupa menyusun suatu sistem yang baru dan menggantikan sistem yang lama secara keseluruhan atau memperbaiki sistem yang telah ada. Metodologi pengembangan sistem E-Customer Relationship Management digambarkan dalam bentuk Fishbone Diagram seperti berikut :

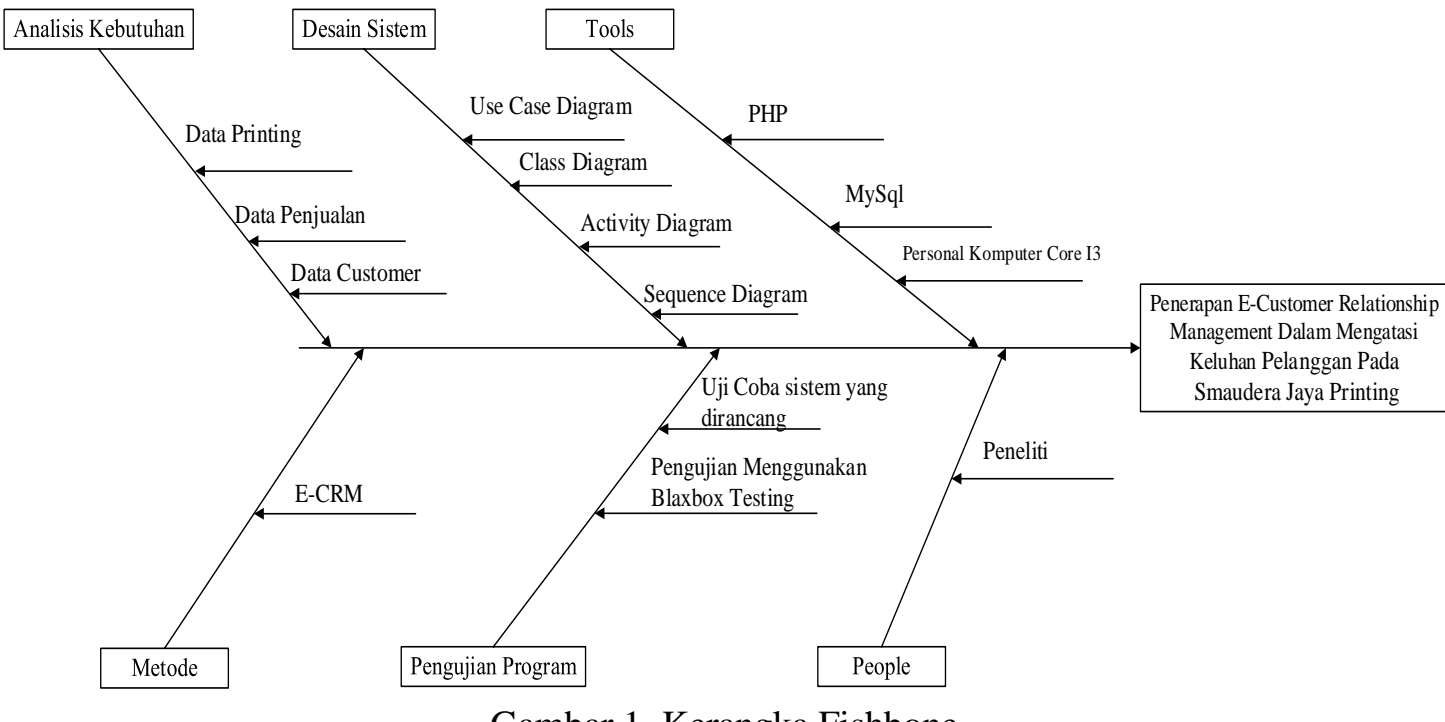

Gambar 1. Kerangka Fishbone

Pemetaan penelitian menggunakan fishbone diagram dapat dijelaskan sebagai berikut :

1. Analisis Kebutuhan

Berisi tentang hal-hal yang harus ada pada hasil perancangan agar mampu menyelesaikan masalah yang ada sesuai tujuan. Data yang dibutuhkan dalam melakukan perancangan sistem 
adalah data printing, data penjualan, data customer, data pengguna dan bahasa pemrograman yang digunakan untuk membuat aplikasi adalah $P H P$.

2. Desain Sistem

Secara umum perancangan sistem pada Penerapan E-Customer Relationship Management dalam pelayanan keluhan pelanggan menggunakan model perancangan Unified Modelling Language yaitu use case diagram, class diagram, activity diagram dan sequence diagram.

3. Tools

Adapun perangkat yang digunakan oleh peneliti yang digunakan untuk membangun sistem yang baru adalah perseonal computer core I3, PHP dan MySql.

4. Metode

Penulis memilih Penerapan E-Customer Relationship Management dalam menyelesaikan laporan penelitian ini dan sangat tepat dalam menyelesaikan permasalahan yang dihadapi oleh perusahaan.

5. Pengujian Program

Pada tahap ini dilakukan pengujian aplikasi secara menyeluruh, meliputi pengujian fungsional dan pengujian ketahanan sistem. Pengujian secara black box (interface) yaitu pengujian perangkat lunak yang tes fungsionalitas dari aplikasi yang bertentangan dengan struktur internal atau kerja. Pengetahuan khusus dari kode aplikasi atau struktur internal dan pengetahuan pemrograman pada umumnya tidak diperlukan, pengujian tersebut untuk masingmasing blok peralatan yang dirancang.

6. People

Pada tahap ini E-Customer Relationship Management dalam mengatasi keluhan pelanggan pada Samudera Jaya Printing sudah melewati tahap validasi dan verifikasi dan siap untuk digunakan oleh Samudera Jaya Printing dan customer dan peneliti.

\section{HASIL DAN PEMBAHASAN}

Samudera Jaya Printing merupakan perusahaan yang bergerak di bidang produksi produk percetakan dan pemesanan produk percetakan yang bertipe make to order (MTO) dimana sistem perencanaan produksi dilakukan setelah ada permintaan. Sistem yang berjalan pada perusahaan masih menggunakan aplikasi sederhana, sehingga pelanggan yang akan memesan produk harus datang langsung atau menghubungi pihak perusahaan untuk melakukan proses pemesanan produk, kemudian pihak perusahaan akan konfirmasi pemesanan produk, setelah itu melakukan proses pembayaran pemesanan produk dengan datang langsung pada perusahaan. Hasil produksi Samudera Jaya Printimg dipasarkan hingga sekitaran luar kota. Seiring dengan misi perusahaan untuk meningkatkan kepuasan dan membina hubungan baik dengan pelanggan, maka dibutuhkan suatu konsep manejem customer yang baik. Salah satu konsep yang dapat diadopsi untuk merespon hal ini adalah dengan menerapkan suatu Customer Relationship Management yang dapat menghubungkan perusahaan dan customer secara langsung (online) yang disebut E-CRM. Melalui pengunaan E-CRM perusahaan bisa mendapatkan manfaat untuk pemesanan, pemasaran, pelayanan dan juga aktivitas perusahaan lainnya. E-CRM juga dapat mempermudah pelanggan dalam mendapatkan informasi yang diperlukan dari perusahaan tersebut. Hal ini menjadi sarana untuk mempertahankan hubungan perusahaan dengan pelanggan demi mewujudkan loyalitas pelanggan, dengan merancang system yang baru maka pelanggan dan pihak perusahaan akan dapat melakukan kerja sama yang baik dengan transaksi pemasaran. Sistem yang dirancang penulis menggunakan pendekatan DRAMA[1].

Penerapan kuesioner yang dilakukan oleh penelitian bertujuan untuk mengetahui tingkat kepuasan pelanggan kepada perusahaan. Kuesioner yang diterapkan perusahaan 5 pilihan mempunyai gradasi dari Sangat Setuju (SS) hingga Sangat Tidak Setuju (STS). 5 pilihan tersebut diantaranya adalah:
a. Sangat Setuju (SS)
b. Setuju (S)
c. Kurang Setuju (KS)
d. Tidak Setuju (TS) 
e. Sangat Tidak Setuju (STS)

Berikut adalah jumlah responden atau pelanggan yang menjawab kuisioner adalah dengan jawaban sebagai berikut :

\begin{tabular}{|c|c|c|c|c|c|}
\hline \multicolumn{6}{|c|}{ Tabel 1. Data Kuesioner } \\
\hline RESPONDEN & $\begin{array}{l}\text { SANGAT } \\
\text { SETUJU }\end{array}$ & SETUJU & $\begin{array}{l}\text { KURANG } \\
\text { SETUJU }\end{array}$ & $\begin{array}{l}\text { TIDAK } \\
\text { SETUJU }\end{array}$ & $\begin{array}{l}\text { SANGAT TIDAK } \\
\text { SETUJU }\end{array}$ \\
\hline Riyan Wijaya & 3 & 32 & 14 & 1 & 0 \\
\hline Bella Putri Lestari & 7 & 30 & 7 & 6 & 0 \\
\hline Feri Gunawan & 1 & 37 & 11 & 1 & 0 \\
\hline Yuni Lestari & 9 & 30 & 7 & 4 & 0 \\
\hline Watik & 2 & 44 & 0 & 4 & 0 \\
\hline Karina Sari & 2 & 38 & 7 & 3 & 0 \\
\hline Efendy Latif & 9 & 31 & 8 & 2 & 0 \\
\hline Agus Rahmadan & 4 & 38 & 6 & 2 & 0 \\
\hline Bukhari & 1 & 47 & 1 & 1 & 0 \\
\hline Andika & 8 & 38 & 4 & 0 & 0 \\
\hline Budi Yanto Nst & 8 & 30 & 10 & 2 & 0 \\
\hline Susan & 5 & 36 & 8 & 0 & 1 \\
\hline Hanifah Ramadahni & 2 & 39 & 9 & 0 & 0 \\
\hline Yamisyah & 4 & 36 & 8 & 2 & 0 \\
\hline NIFARA & 5 & 33 & 9 & 3 & 0 \\
\hline Tamara & 6 & 35 & 7 & 2 & 0 \\
\hline Natasya Putri & 2 & 45 & 1 & 2 & 0 \\
\hline Muhammad Dani & 3 & 39 & 5 & 3 & 0 \\
\hline Redho Syahputra & 3 & 39 & 5 & 3 & 0 \\
\hline Asy-Suffah & 3 & 38 & 8 & 1 & 0 \\
\hline Melinda Dwi Sariani & 6 & 33 & 7 & 4 & 0 \\
\hline Dara Aliya Sari & 8 & 31 & 8 & 3 & 0 \\
\hline Farah Syahira & 6 & 32 & 8 & 4 & 0 \\
\hline Mhd. Bagus & 2 & 42 & 4 & 2 & 0 \\
\hline Yuda Hamdani & 3 & 42 & 4 & 1 & 0 \\
\hline Ponise & 5 & 38 & 6 & 1 & 0 \\
\hline Hardi Hasibuan & 3 & 34 & 10 & 3 & 0 \\
\hline Ummu Syafira & 3 & 36 & 7 & 4 & 0 \\
\hline Khairiyah & 8 & 25 & 12 & 5 & 0 \\
\hline Bayu Atmaja & 2 & 29 & 16 & 3 & 0 \\
\hline Pasya Gunawan & 1 & 33 & 12 & 4 & 0 \\
\hline Alvino Febrian & 0 & 41 & 6 & 3 & 0 \\
\hline Azizah & 4 & 35 & 9 & 2 & 0 \\
\hline Zura & 1 & 37 & 11 & 1 & 0 \\
\hline
\end{tabular}

Untuk pencarian hasil Persentase:

Jumlah Jawaban/ Total Responden x 100

Maka diperoleh hasil;

Tabel 2. Hasil Pengolahan Data Kuesioner

\section{NO}

PERNYATAAAN

SANGAT SETUJU KURANG TIDAK SANGAT
SETUJU TIDAK
SETUU SETUJU SETUJU

$\begin{array}{llllllll}1 & \begin{array}{l}\text { Pelayanan di Samudera Jaya Printing } \\ \text { tepat waktu }\end{array} & 16 \% & 74 \% & 10 \% & 0 \% & 0 \% \\ 2 & \text { Pemeriksaan, pelayanan di Samudera } & 11 \% & 76 \% & 13 \% & 0 \% & 0 \%\end{array}$




$\begin{array}{lll}\text { NO PERNYATAAAN } & \text { SANGAT SETUJU KURANG TIDAK SANGAT } \\ \text { SETUJU SETUJU TIDAK } & \text { SETUJU }\end{array}$

Jaya Printing dilakukan secara tepat

Samudera Jaya Printing memberikan

3 informasi mengenai pelayanan secara jelas

4 Samudera Jaya Printing menjawab

4 keluhan pelanggan

$\begin{array}{lllll}7 \% & 87 \% & 6 \% & 0 \% & 0 \%\end{array}$

5 Samudera Jaya Printing memberikan kesempatan bertanya kepada pelanggan

Samudera Jaya Printing didukung dengan

6 tenaga customer service yang handal

6 sehingga dapat menimbulkan kepercayaan pelanggan

Pelanggan merasa aman untuk membeli

7 atau memesan produk yang ada di Samudera Jaya Printing

8 Pegawai di Samudera Jaya Printing

8 bersikap sopan kepada pelanggan

Samudera Jaya Printing mampu

9 menjawab pertanyaan yang diajukan pelanggan

Samudera Jaya Printing berusaha

10 menenangkan rasa cemas pelanggan terhadap pelayanan yang diderita

Samudera Jaya Printing beroperasi 24

11 jam sehari sehingga pelanggan dapat terlayani

12 Peralatan yang digunakan di Samudera Jaya Printing terlihat canggih

$8 \% \quad 87 \% \quad 5 \% \quad 0 \% \quad 0 \%$

$9 \% \quad 85 \% \quad 5 \% \quad 1 \% \quad 0 \%$

$2 \% \quad 49 \% \quad 42 \% \quad 7 \% \quad 0 \%$

13 Samudera Jaya Printing memiliki alat-

3 alat printing yang cukup lengkap produk yang ditawarkan Samudera Jaya

14 Printing dengan kebutuhan pelanggan sudah sesuai

Tarif jasa pelayanan Samudera Jaya

15 Printing lebih murah dibandingkan dengan yang lain

Samudera Jaya Printing memberikan

16 diskon atas tarif jasa pelayanan yang diberikan

Samudera Jaya Printing menetapkan

17 pungutan-pungutan lain diluar tarif yang sudah ditetapkan

Tarif Jasa pelayanan Samudera Jaya

Printinf sudah sesuai dengan kualitas

18 pelayanan yang diberikan pihak Samudera jaya printing kepada para pelanggan

19 bentuk brosur yang diberikan Samudera Jaya Printing sangat menarik

$19 \% \quad 80 \% \quad 1 \% \quad 0 \% \quad 0 \%$

$\begin{array}{lllll}4 \% & 92 \% & 4 \% & 0 \% & 0 \%\end{array}$

$\begin{array}{lllll}8 \% & 86 \% & 6 \% & 0 \% & 0 \%\end{array}$

$\begin{array}{lllll}12 \% & 85 \% & 3 \% & 0 \% & 0 \%\end{array}$

$\begin{array}{lllll}0 \% & 7 \% & 53 \% & 39 \% & 1 \%\end{array}$

$\begin{array}{lllll}10 \% & 89 \% & 1 \% & 0 \% & 0 \%\end{array}$

$3 \% \quad 54 \% \quad 40 \% \quad 3 \% \quad 0 \%$

$\begin{array}{lllll}6 \% & 90 \% & 4 \% & 0 \% & 0 \%\end{array}$

$11 \% \quad 64 \% \quad 24 \% \quad 1 \% \quad 0 \%$

$\begin{array}{lllll}9 \% & 83 \% & 8 \% & 0 \% & 0 \%\end{array}$

$2 \% \quad 56 \% \quad 39 \% \quad 3 \% \quad 0 \%$

20 Informasi yang erdapat pada brosur yang

$\begin{array}{lllll}1 \% & 49 \% & 47 \% & 3 \% & 0 \% \\ 2 \% & 48 \% & 48 \% & 2 \% & 0 \%\end{array}$




NO PERNYATAAAN $\quad \begin{gathered}\text { SANGAT SETUJU KURANG TIDAK SANGAT } \\ \text { SETUJU SETUJU TIDAK } \\ \text { SETUJU }\end{gathered}$

diberikan Samudera Jaya Printing sangat informatif

Samudera Jaya Printing melakukan

21 kegiatan promosi melalui media massa, sperti koran dan majalah

Samudera Jaya Printing melakukan

22 kegiatan promosi melalui media

elektronik seprti televisi, radio, dan internet

Saya sangat mendukung kegiatan-

23 kegiatan yang dibuat oleh Samudera Jaya

Printing

Lokasi perusahaan terletak di pusat kota

24 yang mudah dijangkau dengan berbagai alat transportasi

25 Lokasi Samudera Jaya Printing sangat strategis, yaitu dekat dengan pusat kota

26 Perusahaan memilih lokasi yang dekat dengan pemukiman penduduk

${ }_{27}$ Perusahaan memiliki tempat parkir yang nyaman

${ }_{28}$ Perusahaan meluangkan waktu khhusus untuk berkomunikasi dengan pelanggan

Perlakuan yang diberikan kepada

29 pelanggan dilakukan untuk kepuasan pelanggan

30 waktu untuk pelayanan pelanggan terpenuhi

$\begin{array}{lllll}26 \% & 64 \% & 8 \% & 2 \% & 0 \%\end{array}$

$1 \% \quad 23 \% \quad 33 \% \quad 43 \% \quad 0 \%$

31 Pegawai senantiasa berpenampilan rapi

32 Ruang di perusahaan tertata rapi, bersih

dan nyaman

$\begin{array}{lllll}6 \% & 93 \% & 1 \% & 0 \% & 0 \%\end{array}$

$1 \% \quad 88 \% \quad 9 \% \quad 2 \% \quad 0 \%$

$\begin{array}{lllll}5 \% & 92 \% & 3 \% & 0 \% & 0 \%\end{array}$

$\begin{array}{lllll}2 \% & 78 \% & 17 \% & 3 \% & 0 \%\end{array}$

$2 \% \quad 77 \% \quad 21 \% \quad 0 \% \quad 0 \%$

33 Saya sangat membutuhkan jasa pelayanan pelanggan

$\begin{array}{lllll}10 \% & 87 \% & 3 \% & 0 \% & 0 \%\end{array}$

Menurut saya jasa pelayanan yang

34 ditawarkan oleh perushaan sangan bermanfaat

35 jasa pelayanan perusahaan sudah dikenal sejak dulu oleh para masyarakat

Sejauh ini jasa pelayanan perusahaan

36 mengalami perkembangan ke arah yang lebih baik

37 Tarif yang dikenakan perusahaan kepada

pelanggan tidak mahal

$1 \% \quad 59 \% \quad 38 \% \quad 2 \% \quad 0 \%$

$\begin{array}{lllll}7 \% & 84 \% & 8 \% & 1 \% & 0 \%\end{array}$

$3 \% \quad 89 \% \quad 8 \% \quad 0 \% \quad 0 \%$

$28 \% \quad 71 \% \quad 1 \% \quad 0 \% \quad 0 \%$

$\begin{array}{lllll}21 \% & 77 \% & 2 \% & 0 \% & 0 \%\end{array}$

$8 \% \quad 87 \% \quad 5 \% \quad 0 \% \quad 0 \%$

$6 \% \quad 65 \% \quad 26 \% \quad 3 \% \quad 0 \%$

38 Perusahaan memiliki tempat yang rapi, bersih dan nyaman

39 Kompetensi tenaga kerja di perusahaan sangat kompeten sekali

Tenaga kerja perusahaan sangat disiplin

40 sekali dalam memberikan pelayanan kepada pelanggan

\begin{tabular}{lllll}
$9 \%$ & $79 \%$ & $11 \%$ & $1 \%$ & $0 \%$ \\
\hline $3 \%$ & $88 \%$ & $9 \%$ & $0 \%$ & $0 \%$ \\
\hline $2 \%$ & $93 \%$ & $5 \%$ & $0 \%$ & $0 \%$ \\
\hline $1 \%$ & $75 \%$ & $24 \%$ & $0 \%$ & $0 \%$
\end{tabular}




\begin{tabular}{|c|c|c|c|c|c|c|}
\hline NO & PERNYATAAAN & $\begin{array}{l}\text { SANGAT } \\
\text { SETUJU }\end{array}$ & SETUJU & $\begin{array}{l}\text { KURANG } \\
\text { SETUJU }\end{array}$ & $\begin{array}{l}\text { TIDAK } \\
\text { SETUJU }\end{array}$ & $\begin{array}{l}\text { SANGAT } \\
\text { TIDAK } \\
\text { SETUJU }\end{array}$ \\
\hline 41 & $\begin{array}{l}\text { sikap kepedulian yang dimiliki tenaga } \\
\text { perushaan sangat baik sekali }\end{array}$ & $4 \%$ & $84 \%$ & $12 \%$ & $0 \%$ & $0 \%$ \\
\hline 42 & $\begin{array}{l}\text { prosedur penerimaan pelanggan di } \\
\text { perusahaan sangat tertib dan cepat sekali }\end{array}$ & $4 \%$ & $44 \%$ & $47 \%$ & $5 \%$ & $0 \%$ \\
\hline 43 & $\begin{array}{l}\text { Kerahasiaan status pelanggan di } \\
\text { perusahaan sangat dirahasiakan sekali }\end{array}$ & $26 \%$ & $69 \%$ & $5 \%$ & $0 \%$ & $0 \%$ \\
\hline 44 & $\begin{array}{l}\text { Kecepatan waktu yang dipakai petugas } \\
\text { pelayanan admnistrasi perusahaan sangat } \\
\text { cepat sekali }\end{array}$ & $4 \%$ & $45 \%$ & $48 \%$ & $3 \%$ & $0 \%$ \\
\hline 45 & $\begin{array}{l}\text { Fasilitas yang ada di perusahaan sangat } \\
\text { memadai sekali }\end{array}$ & $4 \%$ & $89 \%$ & $7 \%$ & $0 \%$ & $0 \%$ \\
\hline 46 & Perlengkapan di perusahaan lengkap & $2 \%$ & $82 \%$ & $16 \%$ & $0 \%$ & $0 \%$ \\
\hline 47 & $\begin{array}{l}\text { Kecepatan proses pelayanan yang } \\
\text { diberikan oleh pihak perusahaan sangat } \\
\text { baik sekali }\end{array}$ & $4 \%$ & $46 \%$ & $49 \%$ & $1 \%$ & $0 \%$ \\
\hline 48 & $\begin{array}{l}\text { Perusahaan sangat tanggap kali atas } \\
\text { keluhan pelanggan }\end{array}$ & $5 \%$ & $92 \%$ & $3 \%$ & $0 \%$ & $0 \%$ \\
\hline 49 & $\begin{array}{l}\text { Samudera Jaya Printing memberi } \\
\text { penjelasan tentang pelayanan }\end{array}$ & $4 \%$ & $86 \%$ & $10 \%$ & $0 \%$ & $0 \%$ \\
\hline 50 & $\begin{array}{l}\text { Samudera Jaya Printing } \\
\text { menanyakan keluhan pelanggan }\end{array}$ & $2 \%$ & $66 \%$ & $32 \%$ & $0 \%$ & $0 \%$ \\
\hline
\end{tabular}

Secara garis besar, bisnis proses sistem yang akan dirancang digambarkan dengan usecase diagram yang terdapat pada Gambar 2 :

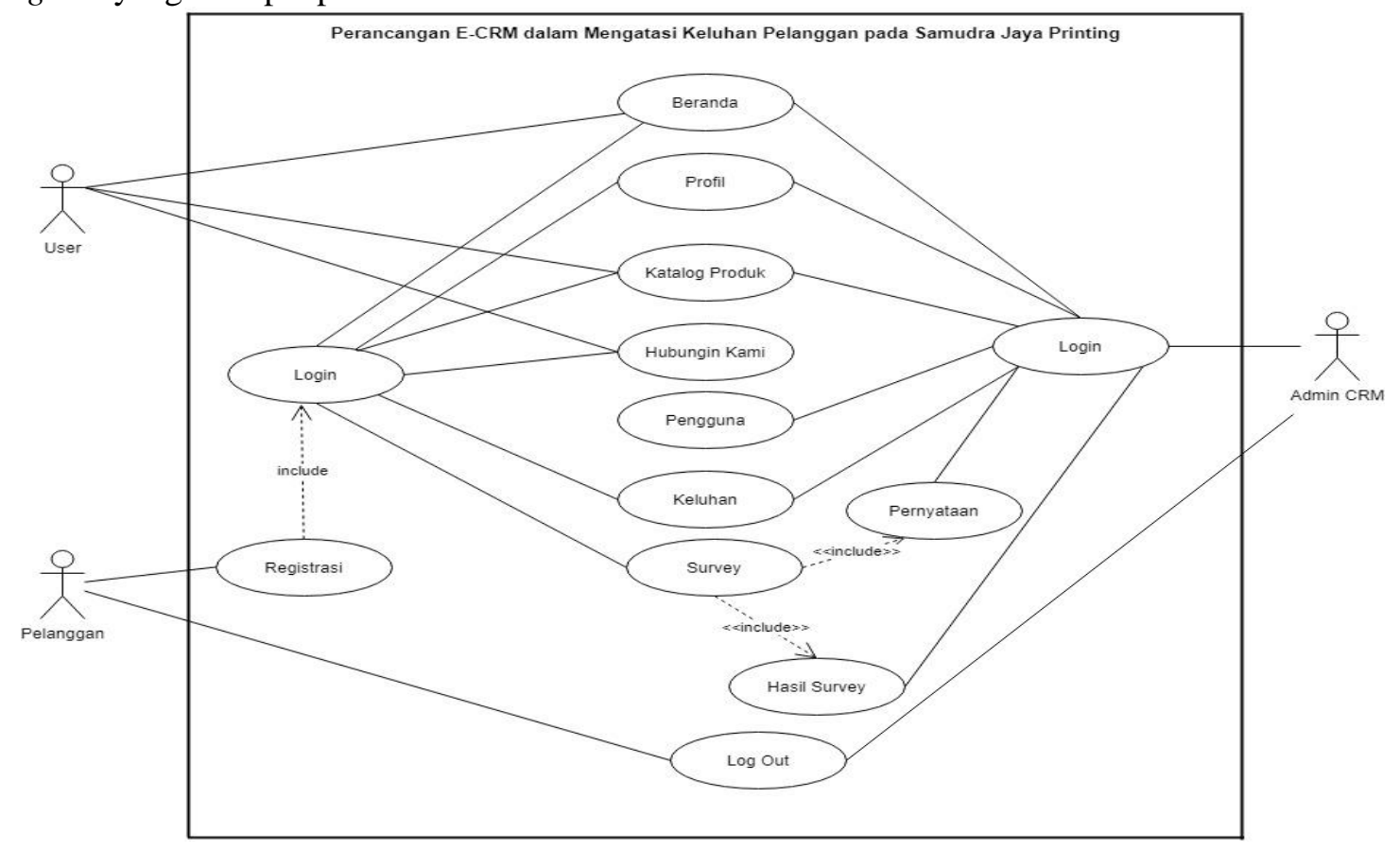

Gambar 2 Use Case Diagram

Rancangan kelas-kelas yang akan digunakan pada sistem yang akan dirancang dapat dilihat pada gambar 3 : 


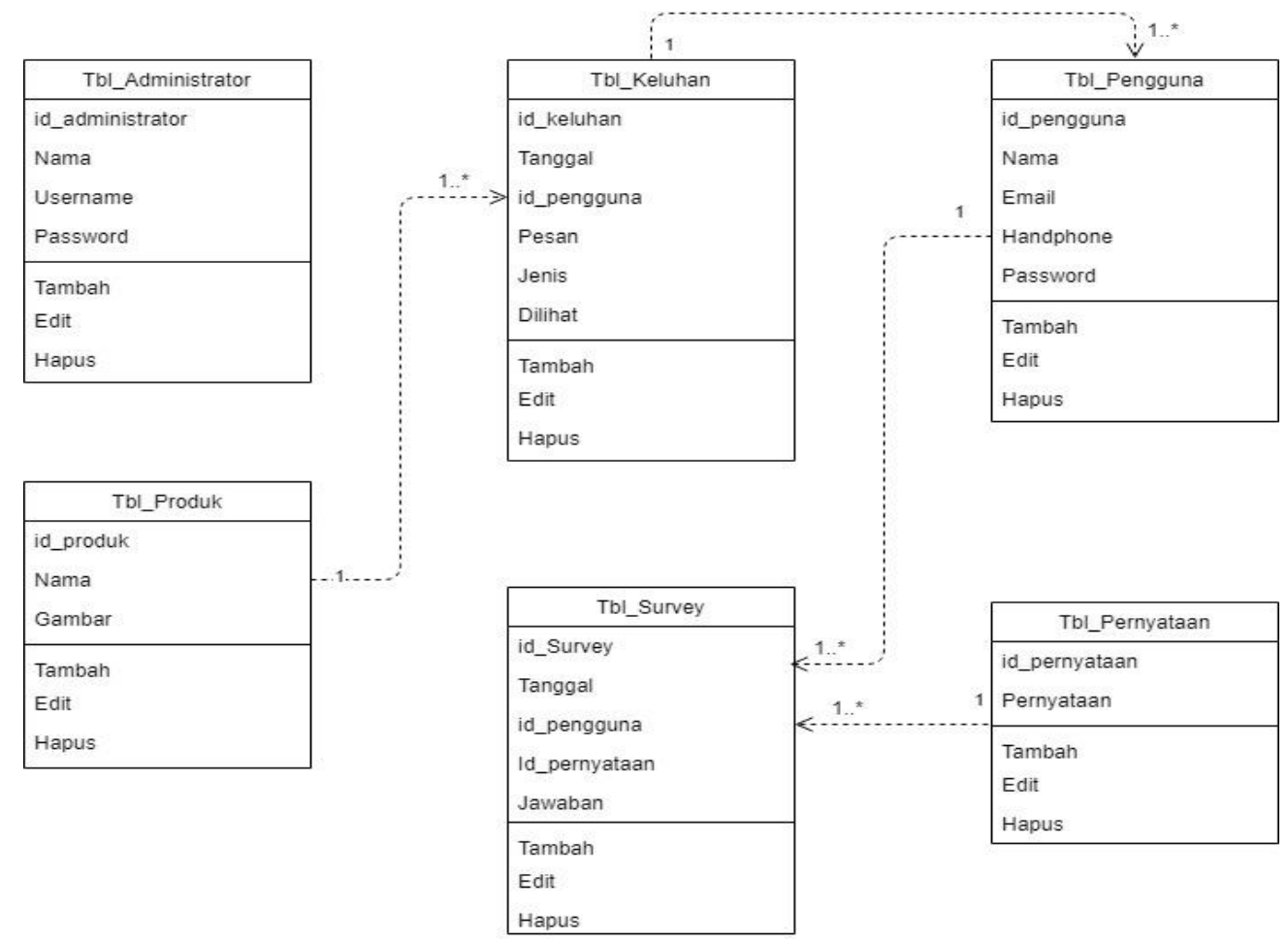

Gambar 3. Class Diagram

\subsection{Tampilan Hasil}

1. Tampilan Form input survey pelanggan

Tampilan ini merupakan tampilan form input data survey yang berfungsi untuk mengetahui tingkat kepuasan survey dari pelanggan. Berikut gambar form input survey pelanggan ditunjukkan pada gambar 4:
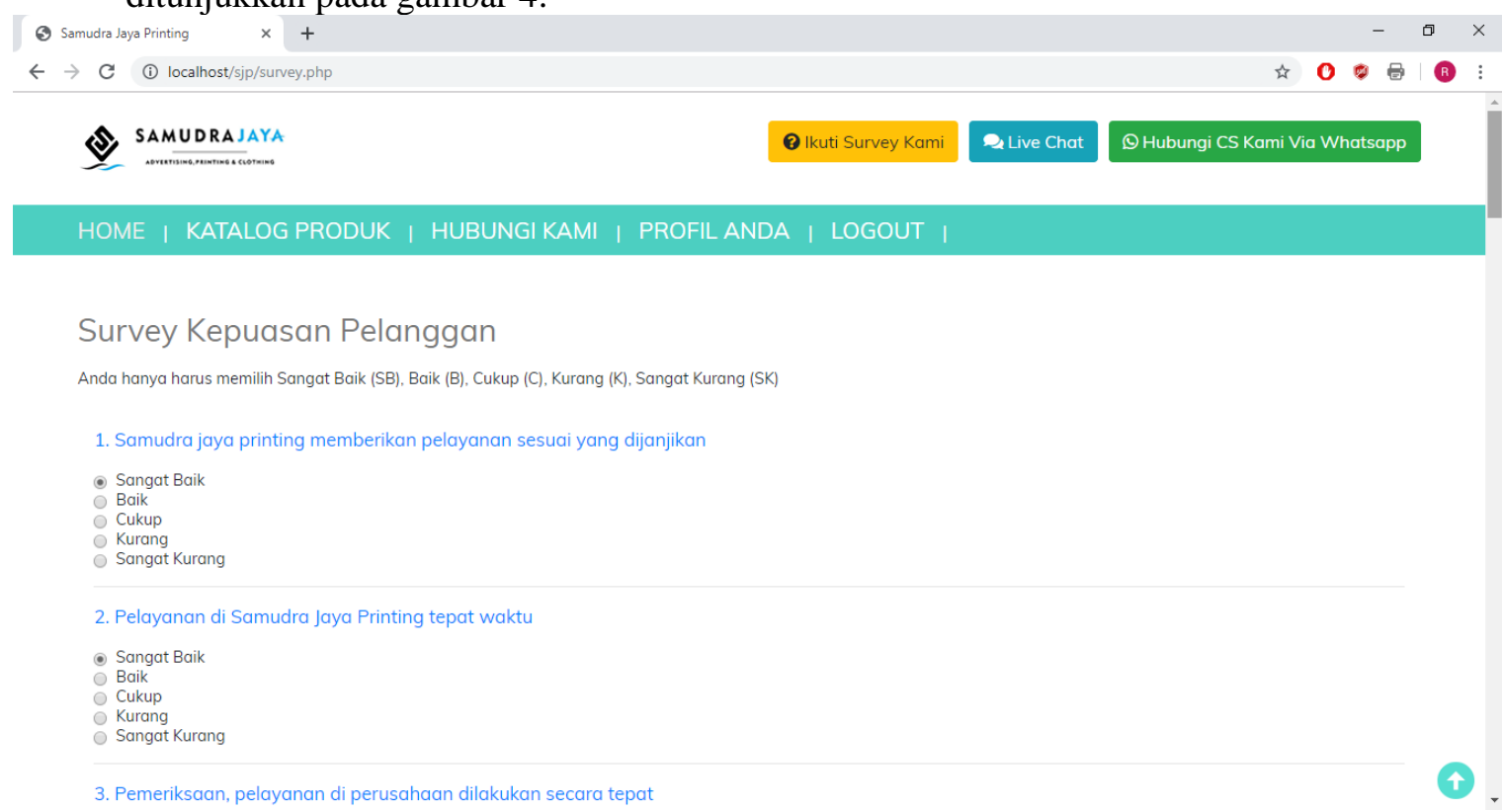

Gambar 4. Tampilan Form inputan survey pelanggan

2. Tampilan Form About Data Komplain

Tampilan ini merupakan tampilan Komplain yang berfungsi untuk mengetahui Komplain.

Gambar tampilan form Komplain pada gambar 5 : 


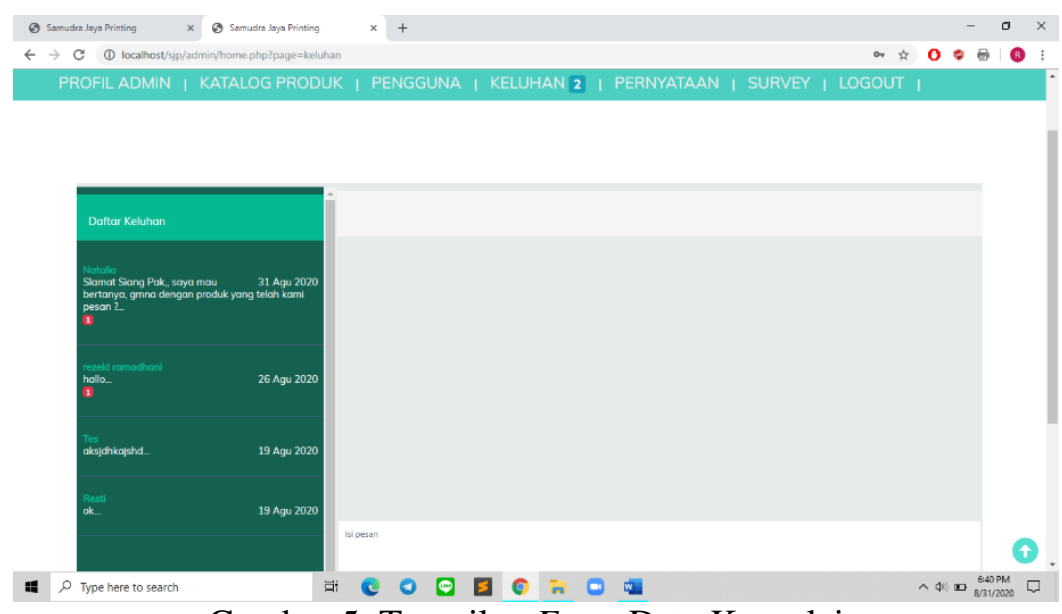

Gambar 5. Tampilan Form Data Komplain berikut :

Adapun kesimpulan penulis mengenai kelebihan dari sistem yang diusulkan adalah sebagai

1. Pada tahap proses penginputan data dan transaksi dapat dilakukan dengan lebih cepat, tepat, akurat dan efisien serta data dapat tersimpan dengan teratur karena sudah ada database untuk menjaga keamanan dari data dan transaksi yang di masukan.

2. Sistem telah didukung dengan sistem basis data modern yang mampu menampung jumlah data dengan kapasitas yang sangat besar, sehingga perusahaan tidak perlu khawatir akan mengalami over capacity data.

3. Sistem mempunyai tampilan yang sangat mudah untuk digunakan dan mampu berinteraksi dengan Pelanggan.

Sistem Informasi E-Customer Relationship Management Pada Samudera Jaya Printing.

Adapun kesimpulan penulis mengenai sistem yang diusulkan adalah:

1. Sistem hanya terbatas pada pengolahan data E-Customer Relationship Management Pada Samudera Jaya Printing, sehingga ketika sistem akan digunakan pada perusahaan yang mempunyai kegiatan yang lebih kompleks (besar), maka sistem tidak akan efektif maupun efesien.

2. Sistem belum mampu dijalankan pada jaringan client server, sehingga sistem yang dibangun tidak dapat dijalankan pada beberapa komputer/laptop.

\section{KESIMPULAN}

Dengan mempelajari berbagai permasalahan yang ada pada Perancangan E-CRM Dalam Mengatasi Keluhan Pelanggan Pada Samudera Jaya Printing, maka dapat diambil beberapa kesimpulan antara lain:

1. Minimnya kesalahan yang terjadi dalam pengolahan data loyalitas pelanggan dan dapat mempermudah dan mempercepat dalam melakukan pelayanan pelanggan.

2. Sistem yang sedang berjalan pada Samudera Jaya Printing telah menggunakan sistem semi komputerisasi sehingga membutuhkan waktu yang lama dalam pencarian, penginputan data maupun dalam pembuatan kuisoner.

3. Perusahaan akan lebih mudah dalam melihat hasil dari pengisian kuisoner yang terjadi dengan sistem yang telah dirancang sehingga meningkatkan kinerja pada Samudera Jaya Printing.

4. Implementasi E-Customer Relationship Management Pada Samudera Jaya Printing dapat memberikan hasil kelayakan penjualan produk Terbaik yang sesuai dengan kebutuhan perusahaan. 


\section{SARAN}

Adapun saran-saran yang akan penulis usulkan untuk penelitian berkelanjutan adalah sebagai berikut :

1. Sistem yang dirancang oleh penulis belum berbasis client server sehingga hasil pengisian kuisoner yang dperolehan tidak dapat dilihat lebih dari satu PC (Personal Computer).

2. Perlunya proses back up data untuk menjaga kenyamanan data.

3. Bila sistem yang penulis usulkan nantinya bisa dikembangkan dengan sistem komputerisasi hendaknya dapat melakukan pelatihan dan menyertakan spesifikasi dari sistem seperti yang telah penulis jelaskan didalam penelitian ini.

4. Sebaknya dilakukan pengembangan sistem yang berbasis android sehingga pelanggan bisa akses kuisoner dengan menggunakan mobile dan mengirim hasil kuisoner dengan menggunakan aplikasi berbasis mobile.

\section{UCAPAN TERIMA KASIH}

Penulis mengucapkan terima kasih kepada Universitas Potensi Utama yang telah banyak memberikan masukkan dan saran dalam penelitian ini.

\section{DAFTAR PUSTAKA}

[1] Chaffey, D., Smith, P. R., \& Smith, P. R. (2013). eMarketing eXcellence: Planning and optimizing your digital marketing. Routledge.

[2] Rahman, A. A., Supaidi, A., Aslamiah, I., \& Ibrahim, A. (2018). Implementasi Customer Relationship Management (Crm) Pelayanan Pelanggan (Corporate) Divisi Bges Pada Pt Telkom Witel Sumsel. JRMSI-Jurnal Riset Manajemen Sains Indonesia, 9(1), 72-78.

[3] Candra, C. (2017). Perancangan Mebel Multifungsi untuk "Daily Treats" Surabaya. Intra, $5(2), 322-331$.

[4] Adnyana, I. M. B. (2016). Perancangan Sistem Informasi Akademik STIKES Wira Medika Bali Berbasis Desktop. Jurnal Sistem dan Informatika (JSI), 10(2), 49-58.

[5] Nst, M. A. E. (2018). SISTEM INFORMASI CUSTOMER RELATIONSHIP MANAGEMENT PADA PT. ANEKA SUSU. IT (INFORMATIC TECHNIQUE) JOURNAL, 5(1), 93-108.

[6] Syahputra, A. B., \& Susianto, S. (2020). ANALISIS PENGARUH KUALITAS PELAYANAN DAN KINERJA CUSTOMER SERVICE TERHADAP KEPUASAN NASABAH (Studi Kasus Nasabah Bank Sumut Syariah Kcpsy Marelan Raya). Jurnal Mahasiswa Fakultas Ekonomi dan Bisnis, 1(1), 477-486.

[7] Wahyuni, E. (2019). ANALISIS FAKTOR-FAKTOR YANG MEMPENGARUHI LOYALITAS KONSUMEN DENGAN KEPUASAN KONSUMEN SEBAGAI VARIABEL INTERVENING PADA TOKO ROTI AROMA MEDAN. Accumulated Journal (Accounting and Management Research Edition), 1(2), 171-182.

[8] Nst, M. A. E. (2018). Perancangan Kualitas Pelayanan Jasa Transportasi Pengiriman Barang Menggunakan Metode Service Quality Pada CV. Karya Agung Medan. IT (INFORMATIC TECHNIQUE) JOURNAL, 6(2), 124-136.

[9] Fujiati, F. (2015). Analisa Sistem Informasi Pelayanan Jasa Import Peti Kemas. 